\title{
Prediksi Curah Hujan Di Kabupaten Majalengka Dengan Menggunakan Algoritma Regresi
}

\author{
Rainfall Prediction in Majalengka District Using Regression \\ Algorithm
}

\author{
Evi Dewi Sri Mulyani ${ }^{1}$, Indah Septianingrum ${ }^{2}$, Nisa Nurjanah ${ }^{3}$, Reka Rahmawati ${ }^{4}$, Syifa \\ Nurhasani ${ }^{5}$, Kiky Milky R K \\ STMIK Tasikmalaya \\ Program Studi Teknik Informatika \\ Jl. R.E. Martadinata No. 272 A Tasikmalaya, Telp. (0265)310830 \\ Email : ${ }^{1}$ eviajadech@gmail.com, 2indahseptianingrum19@gmail.com, ${ }^{3}$ nisanurjanah693@gmail.com \\ 나rahmawatireka@gmail.com,
}

ABSTRAK

Prediksi curah hujan bulanan dengan menggunakan prediktor suhu, kelembapan, lama penyinaran matahari dan kecepatan angin telah dilakukan di Stasiun Meteorologi Jatiwangi Majalengka. Prediksi curah hujan bulanan untuk tahun 2019 dengan menggunakan data parameter cuaca harian periode tahun 2018 di Kabupaten Majalengka telah dilakukan dengan menggunakan metode persamaan regresi linier berganda. Evaluasi yang dilakukan dengan membandingkan dan menghitung besarnya penyimpangan prediksi total hujan bulanan terhadap observasi total hujan bulanan. Hasil pengolahan data yang dilakukan untuk prediksi curah hujan bulanan tahun 2019 menunjukan hasil over estimate (lebih besar dari nilai aktual) dan hasil prediksi paling baik terjadi pada bulan april. Prediksi curah hujan bulanan menghasilkan nilai koefisien korelasi yang kuat dan RMSE yang baik yaitu $r=0,90$ dan RMSE $=40,96 \%$.

Kata Kunci : Curah Hujan, Prediksi, Regresi Linier Berganda,

\section{ABSTRACT}

Monthly rainfall predictions using predictors of air temperature, air pressure, solar radiation and air humidity have been done in Majalengka Jatiwangi Meteorological Station. Monthly rainfall predictions in Majalengka Regency for 2019 using the 2018 daily weather parameter data in Majalengka Regency was formulated using the multiple linear regression equation method. Evaluation is done by comparing and calculating the amount of deviation from monthly rainfall predictions to the monthly rainfall observations. The result of data processing perfomed for monthly rainfall prediction in 2019 show the results was over estimate (bigger than its actual values) and the best prediction results occurred in april. Monthly rainfall predictions produce a strong correlation coefficient and good RMSE where $r=0,90$ and RMSE $=40,96 \%$.

Keyword : Rainfall, Prediction, Multiple Linear Regression

\section{PENDAHULUAN}

Berdasarkan letak astronomi Indonesia terletak di daerah tropis. Dimana curah hujan merupakan salah satu unsur iklim yang paling tinggi keragamannya. Karakteristik curah hujan diberbagai daerah tentunya tidak sama. Kondisi ini diakibatkan oleh beberapa faktor, yakni: geografis, topografis dan orografis. Belum lagi ditambah dengan struktur dan orientasi kepulauan[1]. Akibatnya pola sebaran curah hujan cenderung tidak merata antara daerah yang satu dengan daerah yang lain dalam ruang lingkup yang luas. 
Secara Geografis, Kabupaten Majalengka terletak dibagian timur Provinsi Jawa Barat. Kabupaten Majalengka terletak pada titik koordinat yaitu Sebelah Barat $108^{\circ} 03^{\prime}-108^{\circ} 19$ BT, Sebelah Timur $108^{\circ} 12^{\prime}-108^{\circ} 25^{\prime}$ BT, Sebelah Utara $6^{\circ} 36^{\prime}-5^{\circ} 58^{\prime}$ LU dan Sebelah Selatan $6^{\circ}$ $43^{\prime}-7^{\circ} 44^{\prime}$ sedangkan dilihat dari topografi kota ini memiliki ketinggian berkisar $20-100 \mathrm{~m}$ diatas permuakaan laut. Curah hujan tahunan rata-rata di Kabupaten Majalengka berkisar antara $2.400 \mathrm{~mm}-3.800 \mathrm{~mm} / \mathrm{tahun}$ dengan rata-rata hujan sebanyak 11 hari/bulan.

Saat ini petani di Majalengka masih menerapkan jadwal dan pola tanam berpedoman pada kebiasaan yang turun menurun, antara lain berdasarkan bulan dan terjadinya hujan. Kondisi fluktuasi curah hujan yang tidak menentu pada beberapa tahun terakhir, menyebabkan perencanaan pertanian menjadi tidak optimal sehingga mendatangkan resiko gagal panen.

Penelitian serupa mengenai model prediksi curah hujan dengan metode regresi linear banyak dilakukan. Dengan menggunakan regresi linear berganda akan mengahasilkan output yang relatif lebih baik jika dibandingkan dengan satu parameter cuaca sebagai prediktor[2]. Prediksi total hujan bulanan tahun 2008 di Ternate dengan menggunakan prediktor suhu udara (T) dan menggunakan kelembapan udara $(\mathrm{RH})$ menunjukan nilai prediksi yang cukup baik pada bulan Januari, sedangkan menggunakan suhu dan kelembapan udara (T dan RH) nilai prediksi cukup baik tampak pada bulan Februari[3]. Digunakan sebuah model prediksi dengan pendekatan Nonparametric Bayesian. Kelebihan model-model nonparametrik terletak pada fleksibilitas bentuk dari modelnya, khususnya tidak terdapat asumsi pada bentuk parametriknya[4]. Persamaan regresi linier berganda menghasilkan model output yang relatif lebih baik dengan nilai penyimpangan $32,93 \mathrm{~mm}$ apabila dibandingkan dengan jumlah curah hujan bulanan aktualnya[5].

Dari uraian diatas, maka penulis membuat sebuah model "Prediksi Curah Hujan di Kabupaten Majalengka Dengan Metode Regresi Linier". Dalam kajian ini penulis mengambil data curah hujan, suhu dan kelembapan udara tahun 2019 di Stasiun Meteorologi Jatiwangi Majalengka. Diharapkan dengan adanya model prediksi ini dapat membantu dalam mengetahui curah hujan bulanan pada bulan dan tahun berikutnya yang nantinya bisa membantu petani dalam merencanakan pertanian.

\section{METODE PENELITIAN}

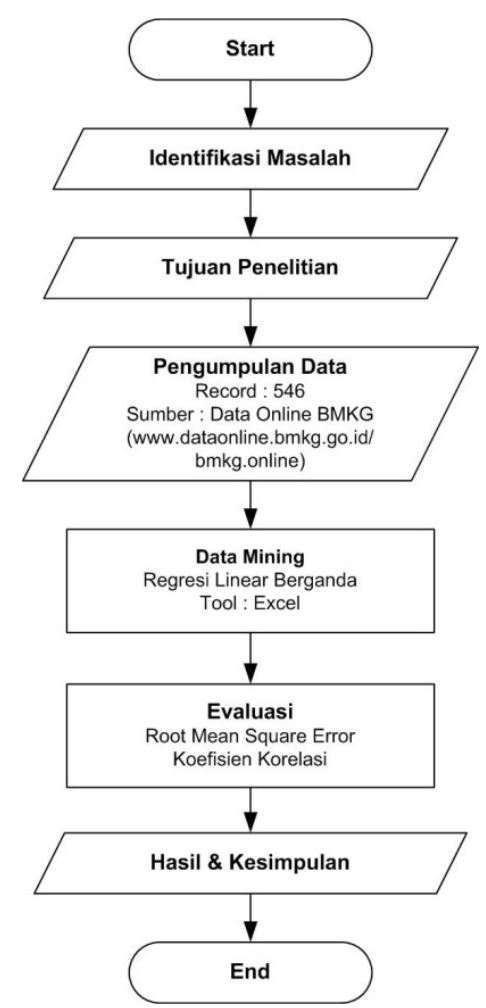

Gambar 1. Flowchart prediksi curah hujan. 
Pada tahap ini diawali dengan mengidentifikasi masalah dan menentukan tujuan untuk membuatkan solusi untuk permasalahan yang ada. Data yang digunakan dalam tulisan ini adalah data iklim yang diperoleh dari Stasiun Meteorologi Jatiwangi Majalengka yang diperoleh dari situs BMKG Online (http://dataonline.bmkg.go.id/bmkg.online), yang terdiri atas data series harian curah hujan, suhu udara, kelembapan udara, lama penyinaran matahari dan kecepatan angin. Data kemudian dihitung secara manual dengan menggunakan bantuan Microsoft Excel.

Metode prediksi yang digunakan dalam penelitian ini adalah Regresi Linear Berganda. Metode prediksi regresi linier berganda ini dilakukan dengan cara membentuk persamaan regresi yang digunakan untuk melakukan prediksi curah hujan bulanan menggunakan lebih dari dari satu variabel independen. Persamaan umum metode ini adalah sebagai berikut:

$$
\mathrm{Y}=\mathrm{A}+\mathrm{B} 1 \mathrm{X} 1+\mathrm{B} 2 \mathrm{X} 2+\ldots \ldots . \mathrm{BnXn}
$$

dimana $: \mathrm{Y}=$ Variabel dependen $; \mathrm{Xi}=$ Variabel independen; $\mathrm{Bi}=$ Koefisien variable $; \mathrm{A}=$ Konstanta.

Metode Evaluasi yang digunakan dalam penelitian ini adalah root mean square error (RMSE) dan koefisien korelasi. RMSE adalah ukuran yang sering digunakan dari perbedaan antara nilai-nilai diprediksi oleh model atau estimator dan nilai-nilai benar-benar diamati. RMSE digunakan untuk mengetahui besarnya penyimpangan yang terjadi antara nilai prediksi curah hujan dibandingkan dengan nilai curah hujan aktualnya (observasi) yang terjadi selama satu tahun. Karena tingkat kesalahan yang dapat diminimalisir dapat meningkatkan tingkat akurasi prakiraan.

$$
\operatorname{RMSE}=\left[\frac{1}{N} \sum_{n=1}^{N}\left(f_{n}-r_{n}\right)^{2}\right]^{\frac{1}{2}}
$$

Dimana $: f_{n}=$ Data curah hujajn hasil observasi; $r_{n}=$ data curah hujan hasil prediksi.

Kuat tidaknya hubungan antara prediksi curah hujan bulanan dengan curah hujan observasinya dapat diukur dengan suatu nilai yang disebut dengan koefisien korelasi. Nilai koefisien korelasi ini paling sedikit -1 dan paling besar 1 . Untuk validasi hasil prakiraan dengan menggunakan koefisien korelasi, semakin kuat korelasi semakin baik hasil validasi berarti semakin tinggi tingkat akurasi perkiraan.

$$
r=\sqrt{1-\frac{\sum(Y-\bar{Y})^{2}}{\sum(Y-Y *)^{2}}}
$$

Dimana $: \mathrm{r}=$ nilai korelasi $; \mathrm{Y}=$ data curah hujan bulanan observasi; $\mathrm{Y}^{*}$ data curah hujan bulanan hasil prediksi; $\bar{\Upsilon}=$ rata-rata data curah hujan bulanan observasi.

\section{HASIL DAN PEMBAHASAN}

Prediksi curah hujan bulanan menggunakan dataset yang diambil pada database BMKG Online dari Stasiun Meteorologi Jatiwangi Majalengka. Data series panjang (periode 2018 - 2019) digunakan untuk melihat pola tren untuk menghitung persamaan predictor. Persamaan tersebut digunakan untuk menghitung nilai curah hujan periode 2019 yang terjadi di wilayah majalengka. Selanjutnya akan divalidasi hasil prediksi hujan terhadap data curah hujan observasi periode 2019.

Tabel 1. Data Set Iklim Harian

\begin{tabular}{|l|l|c|c|c|c|c|}
\hline No & Tanggal & Suhu & Kelembapan & $\begin{array}{c}\text { Lama } \\
\text { Penyinaran }\end{array}$ & $\begin{array}{c}\text { Kecepatan } \\
\text { Angin }\end{array}$ & $\begin{array}{c}\text { Curah } \\
\text { Hujan }\end{array}$ \\
\hline $\mathbf{1}$ & $01-01-2018$ & 28,1 & 81 & 6,4 & 1 & 39,3 \\
\hline $\mathbf{2}$ & $02-01-2018$ & 26,9 & 83 & 2,2 & 1 & 0 \\
\hline $\mathbf{3}$ & $03-01-2018$ & 27,2 & 85 & 5 & 1 & 23,9 \\
\hline $\mathbf{4}$ & $04-01-2018$ & 25,7 & 94 & 5,1 & 0 & 88 \\
\hline $\mathbf{5}$ & $05-01-2018$ & 26,7 & 88 & 1,6 & 1 & 23 \\
\hline
\end{tabular}




\begin{tabular}{|l|l|c|c|c|c|c|}
\hline No & Tanggal & Suhu & Kelembapan & $\begin{array}{c}\text { Lama } \\
\text { Penyinaran }\end{array}$ & $\begin{array}{c}\text { Kecepatan } \\
\text { Angin }\end{array}$ & $\begin{array}{c}\text { Curah } \\
\text { Hujan }\end{array}$ \\
\hline$\cdots$ & $\cdots$ & $\cdots$ & $\cdots$ & $\cdots$ & $\cdots$ & $\cdots$ \\
\hline $\mathbf{5 5 4}$ & $30-06-2019$ & 26,8 & 64 & 9,5 & 1 & 0 \\
\hline
\end{tabular}

Berikut langkah pengerjaan dari prediksi curah hujan di Majalengka :

1. Mempersiapkan data set periode 2018 dengan pengelompokan secara perbulan

Tabel 2. Data Set Iklim Harian pada Bulan Januari

\begin{tabular}{|c|c|c|c|c|c|c|}
\hline No & Tanggal & Suhu & Kelembapan & $\begin{array}{c}\text { Lama } \\
\text { Penyinaran }\end{array}$ & $\begin{array}{c}\text { Kecepatan } \\
\text { Angin }\end{array}$ & $\begin{array}{c}\text { Curah } \\
\text { Hujan }\end{array}$ \\
\hline $\mathbf{1}$ & $01-01-2018$ & 28,1 & 81 & 6,4 & 1 & 39,3 \\
\hline $\mathbf{2}$ & $02-01-2018$ & 26,9 & 83 & 2,2 & 1 & 0 \\
\hline $\mathbf{3}$ & $03-01-2018$ & 27,2 & 85 & 5 & 1 & 23,9 \\
\hline $\mathbf{4}$ & $04-01-2018$ & 25,7 & 94 & 5,1 & 0 & 88 \\
\hline $\mathbf{5}$ & $05-01-2018$ & 26,7 & 88 & 1,6 & 1 & 23 \\
\hline $\mathbf{6}$ & $06-01-2018$ & 26,4 & 87 & 4,5 & 1 & 21,4 \\
\hline $\mathbf{7}$ & $07-01-2018$ & 26,8 & 86 & 1,2 & 0 & 88 \\
\hline $\mathbf{8}$ & $08-01-2018$ & 28,2 & 83 & 0,2 & 1 & 0,5 \\
\hline $\mathbf{9}$ & $09-01-2018$ & 28,2 & 81 & 3,6 & 1 & 0 \\
\hline $\mathbf{1 0}$ & $10-01-2018$ & 26,9 & 83 & 6,9 & 1 & 88 \\
\hline $\mathbf{1 1}$ & $11-01-2018$ & 26,7 & 82 & 7,6 & 1 & 39,1 \\
\hline $\mathbf{1 2}$ & $12-01-2018$ & 27,5 & 80 & 3,2 & 2 & 0 \\
\hline $\mathbf{1 3}$ & $13-01-2018$ & 27,4 & 77 & 3,5 & 2 & 0 \\
\hline $\mathbf{1 4}$ & $14-01-2018$ & 26,1 & 85 & 0 & 1 & 88 \\
\hline $\mathbf{1 5}$ & $15-01-2018$ & 26,3 & 84 & 0,4 & 1 & 0,1 \\
\hline $\mathbf{1 6}$ & $16-01-2018$ & 26,9 & 77 & 1,3 & 2 & 0 \\
\hline $\mathbf{1 7}$ & $17-01-2018$ & 27,2 & 80 & 3,4 & 1 & 88 \\
\hline $\mathbf{1 8}$ & $18-01-2018$ & 26,4 & 88 & 1,8 & 1 & 0 \\
\hline & & & & & & \\
\hline & & & & & & \\
\hline
\end{tabular}




\begin{tabular}{|c|c|c|c|c|c|c|}
\hline $\mathbf{N o}$ & Tanggal & Suhu & Kelembapan & $\begin{array}{c}\text { Lama } \\
\text { Penyinaran }\end{array}$ & $\begin{array}{c}\text { Kecepatan } \\
\text { Angin }\end{array}$ & $\begin{array}{c}\text { Curah } \\
\text { Hujan }\end{array}$ \\
\hline $\mathbf{1 9}$ & $19-01-2018$ & 27,4 & 83 & 2,4 & 1 & 0,3 \\
\hline $\mathbf{2 0}$ & $20-01-2018$ & 26,9 & 85 & 1,5 & 1 & 88 \\
\hline $\mathbf{2 1}$ & $21-01-2018$ & 26,6 & 87 & 1,5 & 1 & 0 \\
\hline $\mathbf{2 2}$ & $22-01-2018$ & 26,6 & 85 & 2,1 & 1 & 13 \\
\hline $\mathbf{2 3}$ & $23-01-2018$ & 27 & 84 & 0,6 & 1 & 88 \\
\hline $\mathbf{2 4}$ & $24-01-2018$ & 27,3 & 85 & 4,6 & 1 & 0,1 \\
\hline $\mathbf{2 5}$ & $25-01-2018$ & 28 & 77 & 5,7 & 1 & 88 \\
\hline $\mathbf{2 6}$ & $26-01-2018$ & 27,4 & 79 & 4,8 & 1 & 0 \\
\hline $\mathbf{2 7}$ & $27-01-2018$ & 27,3 & 80 & 5,2 & 2 & 0,1 \\
\hline $\mathbf{2 8}$ & $28-01-2018$ & 27 & 77 & 4,2 & 2 & 88 \\
\hline $\mathbf{2 9}$ & $29-01-2018$ & 27,4 & 78 & 0,9 & 1 & 88 \\
\hline $\mathbf{3 0}$ & $30-01-2018$ & 27,1 & 83 & 4,8 & 2 & 0,1 \\
\hline $\mathbf{3 1}$ & $31-01-2018$ & 27,4 & 84 & 5,3 & 1 & 0,8 \\
\hline
\end{tabular}

2. Menentukan variable bebas dan variable tidak bebas

- Variable bebas :

Suhu (X1)

Kelembapan (X2)

Lama Penyinaran (X3)

Kecepatan Angin (X4)

- Variable tidak bebas :

Curah Hujan (Y)

3. Setelah menentukan variabel bebas dan variabel tak bebas selanjutnya mencari nilai persamaan regresi linear. 
Tabel 3. Ikhtisar Perhitungan

\begin{tabular}{|c|c|c|c|c|c|c|c|c|c|c|c|c|c|c|}
\hline No & $\mathrm{Xl}^{2}$ & $\mathrm{X} \mathbf{2}^{2}$ & $\mathrm{X}^{2}{ }^{2}$ & $\mathrm{X} 4^{2}$ & $\mathrm{X} 1 * \mathrm{X} 2$ & $\mathrm{Xl}{ }^{*} \mathrm{X} 3$ & $\mathrm{X1} * \mathrm{X} 4$ & $\mathrm{X} 2 * \mathrm{X} 3$ & $\mathrm{X} 2 * \mathrm{X} 4$ & $\mathrm{X} 3 * \mathrm{X} 4$ & $\mathrm{Xl} * \mathrm{Y}$ & $\mathrm{X} 2 * \mathrm{Y}$ & $\mathrm{X}^{*} * \mathrm{Y}$ & $\mathrm{X} 4$ * $\mathrm{Y}$ \\
\hline 1 & 789,61 & 6561 & 40,96 & 1 & 2276,1 & 179,84 & 28,1 & 518,4 & 81 & 6,4 & 1104,33 & 3183,3 & 251,52 & 39,3 \\
\hline 2 & 723,61 & 6889 & 4,84 & 1 & 2232,7 & 59,18 & 26,9 & 182,6 & 83 & 2,2 & 0 & 0 & 0 & 0 \\
\hline 3 & 739,84 & 7225 & 25 & 1 & 2312 & 136 & 27,2 & 425 & 85 & 5 & 650,08 & 2031,5 & 119,5 & 23,9 \\
\hline 4 & 660,49 & 8836 & 26,01 & 0 & 2415,8 & 131,07 & 0 & 479,4 & 0 & 0 & 2261,6 & 8272 & 448,8 & 0 \\
\hline 5 & 712,89 & 7744 & 2,56 & 1 & 2349,6 & 42,72 & 26,7 & 140,8 & 88 & 1,6 & 614,1 & 2024 & 36,8 & 23 \\
\hline 6 & 696,96 & 7569 & 20,25 & 1 & 2296,8 & 118,8 & 26,4 & 391,5 & 87 & 4,5 & 564,96 & 1861,8 & 96,3 & 21,4 \\
\hline 7 & 718,24 & 7396 & 1,44 & 0 & 2304,8 & 32,16 & 0 & 103,2 & 0 & 0 & 2358,4 & 7568 & 105,6 & 0 \\
\hline 8 & 795,24 & 6889 & 0,04 & 1 & 2340,6 & 5,64 & 28,2 & 16,6 & 83 & 0,2 & 14,1 & 41,5 & 0,1 & 0,5 \\
\hline 9 & 795,24 & 6561 & 12,96 & 1 & 2284,2 & 101,52 & 28,2 & 291,6 & 81 & 3,6 & 0 & 0 & 0 & 0 \\
\hline 10 & 723,61 & 6889 & 47,61 & 1 & 2232,7 & 185,61 & 26,9 & 572,7 & 83 & 6,9 & 2367,2 & 7304 & 607,2 & 88 \\
\hline 11 & 712,89 & 6724 & 57,76 & 1 & 2189,4 & 202,92 & 26,7 & 623,2 & 82 & 7,6 & 1043,97 & 3206,2 & 297,16 & 39,1 \\
\hline 12 & 756,25 & 6400 & 10,24 & 4 & 2200 & 88 & 55 & 256 & 160 & 6,4 & 0 & 0 & 0 & 0 \\
\hline 13 & 750,76 & 5929 & 12,25 & 4 & 2109,8 & 95,9 & 54,8 & 269,5 & 154 & 7 & 0 & 0 & 0 & 0 \\
\hline 14 & 681,21 & 7225 & 0 & 1 & 2218,5 & 0 & 26,1 & 0 & 85 & 0 & 2296,8 & 7480 & 0 & 88 \\
\hline 15 & 691,69 & 7056 & 0,16 & 1 & 2209,2 & 10,52 & 26,3 & 33,6 & 84 & 0,4 & 2,63 & 8,4 & 0,04 & 0,1 \\
\hline 16 & 723,61 & 5929 & 1,69 & 4 & 2071,3 & 34,97 & 53,8 & 100,1 & 154 & 2,6 & 0 & 0 & 0 & 0 \\
\hline 17 & 739,84 & 6400 & 11,56 & 1 & 2176 & 92,48 & 27,2 & 272 & 80 & 3,4 & 2393,6 & 7040 & 299,2 & 88 \\
\hline 18 & 696,96 & 7744 & 3,24 & 1 & 2323,2 & 47,52 & 26,4 & 158,4 & 88 & 1,8 & 0 & 0 & 0 & 0 \\
\hline 19 & 750,76 & 6889 & 5,76 & 1 & 2274,2 & 65,76 & 27,4 & 199,2 & 83 & 2,4 & 8,22 & 24,9 & 0,72 & 0,3 \\
\hline 20 & 723,61 & 7225 & 2,25 & 1 & 2286,5 & 40,35 & 26,9 & 127,5 & 85 & 1,5 & 2367,2 & 7480 & 132 & 88 \\
\hline 21 & 707,56 & 7569 & 2,25 & 1 & 2314,2 & 39,9 & 26,6 & 130,5 & 87 & 1,5 & 0 & 0 & 0 & 0 \\
\hline 22 & 707,56 & 7225 & 4,41 & 1 & 2261 & 55,86 & 26,6 & 178,5 & 85 & 2,1 & 345,8 & 1105 & 27,3 & 13 \\
\hline 23 & 729 & 7056 & 0,36 & 1 & 2268 & 16,2 & 27 & 50,4 & 84 & 0,6 & 2376 & 7392 & 52,8 & 88 \\
\hline 24 & 745,29 & 7225 & 21,16 & 1 & 2320,5 & 125,58 & 27,3 & 391 & 85 & 4,6 & 2,73 & 8,5 & 0,46 & 0,1 \\
\hline 25 & 784 & 5929 & 32,49 & 1 & 2156 & 159,6 & 28 & 438,9 & 77 & 5,7 & 2464 & 6776 & 501,6 & 88 \\
\hline 26 & 750,76 & 6241 & 23,04 & 1 & 2164,6 & 131,52 & 27,4 & 379,2 & 79 & 4,8 & 0 & 0 & 0 & 0 \\
\hline 27 & 745,29 & 6400 & 27,04 & 4 & 2184 & 141,96 & 54,6 & 416 & 160 & 10,4 & 2,73 & 8 & 0,52 & 0,2 \\
\hline 28 & 729 & 5929 & 17,64 & 4 & 2079 & 113,4 & 54 & 323,4 & 154 & 8,4 & 2376 & 6776 & 369,6 & 176 \\
\hline 29 & 750,76 & 6084 & 0,81 & 1 & 2137,2 & 24,66 & 27,4 & 70,2 & 78 & 0,9 & 2411,2 & 6864 & 79,2 & 88 \\
\hline 30 & 734,41 & 6889 & 23,04 & 4 & 2249,3 & 130,08 & 54,2 & 398,4 & 166 & 9,6 & 2,71 & 8,3 & 0,48 & 0,2 \\
\hline 31 & 750,76 & 7056 & 28,09 & 1 & 2301,6 & 145,22 & 27,4 & 445,2 & 84 & 5,3 & 21,92 & 67,2 & 4,24 & 0,8 \\
\hline Jumlah & 22717,7 & 213683 & 466,91 & 47 & 69538,8 & 2754,94 & 949,7 & 8383 & 2865 & 117,4 & 28050,28 & 86530,6 & 3431,14 & 953,9 \\
\hline
\end{tabular}

Tabel diatas merupakan ikhtisar perhitungan dimana untuk mempermudah melihat jumlah dari nilai perkalian $\mathrm{X}$ dan $\mathrm{Y}$.

4. Selanjutnya Untuk memperoleh koefisien regresi a, b1, b2, b3 dan b4 dapat diperoleh dengan cara simultan dari lima persamaan sebagai berikut:

$$
\begin{aligned}
& a n+b 1 \Sigma \mathrm{X} 1+b 2 \Sigma \mathrm{X} 2+b 3 \Sigma \mathrm{X} 3+b 4 \Sigma \mathrm{X} 4=\Sigma \mathrm{Y} \\
& a \Sigma \mathrm{X} 1+b 1 \Sigma \mathrm{X} 1^{2}+b 2 \Sigma \mathrm{X} 1 \mathrm{X} 2+b 3 \Sigma \mathrm{X} 1 \mathrm{X} 3+b 4 \Sigma \mathrm{X} 1 \mathrm{X} 4=\Sigma \mathrm{X} 1 \mathrm{Y} \\
& a \Sigma \mathrm{X} 2+b 1 \Sigma \mathrm{X} 1 \mathrm{X} 2+b 2 \Sigma \mathrm{X} 2^{2}+b 3 \Sigma \mathrm{X} 2 \mathrm{X} 3+b 4 \Sigma \mathrm{X} 2 \mathrm{X} 4=\Sigma \mathrm{X} 2 \mathrm{Y} \\
& a \Sigma \mathrm{X} 3+b 1 \Sigma \mathrm{X} 1 \mathrm{X} 3+b 2 \Sigma \mathrm{X} 2 \mathrm{X} 3+b 3 \Sigma \mathrm{X} 3^{2}+b 4 \Sigma \mathrm{X} 34=\Sigma \mathrm{X} 2 \mathrm{Y} \\
& a \Sigma \mathrm{X} 4+b 1 \Sigma \mathrm{X} 1 \mathrm{X} 4+b 2 \Sigma \mathrm{X} 2 \mathrm{X} 4+b 3 \Sigma \mathrm{X} 34+b 4 \Sigma \mathrm{X} 4^{2}=\Sigma \mathrm{X} 2 \mathrm{Y} \\
& \text { Mengikuti rumus persamaan di atas maka di peroleh }: \\
& 31+839 \mathrm{~b} 1+2571 \mathrm{~b} 2+101,5 \mathrm{~b} 3+35 \mathrm{~b} 4=1041,7 \\
& 839+22717,7 \mathrm{~b} 1+69538,8 \mathrm{~b} 2+2754,94 \mathrm{~b} 3+949,7 \mathrm{~b} 4=28050,28 \\
& 2571+69538,8 \mathrm{~b} 1+213683 \mathrm{~b} 2+8383 \mathrm{~b} 3+2865 \mathrm{~b} 4=86530,6 \\
& 101,5+2754,94 \mathrm{~b} 1+8383 \mathrm{~b} 2+466,91 \mathrm{~b} 3+117,4 \mathrm{~b} 4=3431,14 \\
& 35+949,7 \mathrm{~b} 1+2865 \mathrm{~b} 2+117,4 \mathrm{~b} 3+47 \mathrm{~b} 4=953,9
\end{aligned}
$$

Selanjutnya kelima persamaan di atas kita masukan pada perhitungan matriks invers untuk menemukan a, b1,b2, b3 dan b4 sebagai berikut :

A

B

\begin{tabular}{|l|l|l|l|l||c|}
\hline 31 & 839 & 2571 & 101,5 & 35 & 1041,7 \\
\hline 839 & 22717,7 & 69538,8 & 2754,94 & 949,7 & 28050,28 \\
\hline 2571 & 69538,8 & 213683 & 8383 & 2865 & 86530,6 \\
\hline 101,5 & 2754,94 & 8383 & 466,91 & 117,4 & 3431,14 \\
\hline 35 & 949,7 & 2865 & 117,4 & 47 & 953,9 \\
\hline
\end{tabular}


- Hitung matriks invers A

\begin{tabular}{|c|c|c|c|c|}
\hline 31 & 839 & 2571 & 101,5 & 35 \\
\hline 839 & 22717,7 & 69538,8 & 2754,94 & 949,7 \\
\hline 2571 & 69538,8 & 213683 & 8383 & 2865 \\
\hline 101,5 & 2754,94 & 8383 & 466,91 & 117,4 \\
\hline 35 & 949,7 & 2865 & 117,4 & 47 \\
\hline
\end{tabular}

- Tambahkan matriks di sebelah kanan dan hitung matriks perbaris

\begin{tabular}{|l|l|l|l|c|c|c|c|c|c|}
\hline 31 & 839 & 2571 & 101,5 & 35 & 1 & 0 & 0 & 0 & 0 \\
\hline 839 & 22717,7 & 69538,8 & 2754,94 & 949,7 & 0 & 1 & 0 & 0 & 0 \\
\hline 2571 & 69538,8 & 213683 & 8383 & 2865 & 0 & 0 & 1 & 0 & 0 \\
\hline 101,5 & 2754,94 & 8383 & 466,91 & 117,4 & 0 & 0 & 0 & 1 & 0 \\
\hline 35 & 949,7 & 2865 & 117,4 & 47 & 0 & 0 & 0 & 0 & 1 \\
\hline
\end{tabular}

$\mathrm{B} 1 / 31$

\begin{tabular}{|l|l|l|l|l|l|l|l|l|l|}
\hline 1 & 27,06 & 82,94 & 3,27 & 1,13 & 0,03 & 0 & 0 & 0 & 0 \\
\hline 839 & 22717,7 & 69538,8 & 2754,94 & 949,7 & 0 & 1 & 0 & 0 & 0 \\
\hline 2571 & 69538,8 & 213683 & 8383 & 2865 & 0 & 0 & 1 & 0 & 0 \\
\hline 101,5 & 2754,94 & 8383 & 466,91 & 117,4 & 0 & 0 & 0 & 1 & 0 \\
\hline 35 & 949,7 & 2865 & 117,4 & 47 & 0 & 0 & 0 & 0 & 1 \\
\hline
\end{tabular}

$\mathrm{B} 2 * \mathrm{~B} 1-\mathrm{B} 2$

$B 3 * B 1-B 3$

$B 4 * B 1-B 4$

$\mathrm{B} 5{ }^{*} \mathrm{~B} 1-\mathrm{B} 5$

\begin{tabular}{|l|l|l|l|l|c|c|c|c|c|}
\hline 1 & 27,06 & 82,94 & 3,27 & 1,13 & 0,03 & 0 & 0 & 0 & 0 \\
\hline 0 & 10,57 & $-44,07$ & 7,89 & 2,44 & $-27,06$ & 1 & 0 & 0 & 0 \\
\hline 0 & $-44,07$ & 455,87 & $-34,95$ & $-37,74$ & $-82,94$ & 0 & 1 & 0 & 0 \\
\hline 0 & 7,89 & $-34,95$ & 134,57 & 2.80 & $-3,27$ & 0 & 0 & 1 & 0 \\
\hline 0 & 2,44 & $-37,74$ & 2,80 & 7,48 & $-1,13$ & 0 & 0 & 0 & 1 \\
\hline
\end{tabular}

$\mathrm{B} 2 / 10,57$

\begin{tabular}{|l|l|l|l|l|c|c|c|c|c|}
\hline 1 & 27,06 & 82,94 & 3,27 & 1,13 & 0,03 & 0 & 0 & 0 & 0 \\
\hline 0 & 1 & $-4,17$ & 0,75 & 0,23 & $-2,56$ & 0,09 & 0 & 0 & 0 \\
\hline 0 & $-44,07$ & 455,87 & $-34,95$ & $-37,74$ & $-82,94$ & 0 & 1 & 0 & 0 \\
\hline 0 & 7,89 & $-34,95$ & 134,57 & 2.80 & $-3,27$ & 0 & 0 & 1 & 0 \\
\hline 0 & 2,44 & $-37,74$ & 2,80 & 7,48 & $-1,13$ & 0 & 0 & 0 & 1 \\
\hline
\end{tabular}

$\mathrm{B} 1{ }^{*} \mathrm{~B} 2-\mathrm{B} 1$

B3*B2-B3

$\mathrm{B} 4 * \mathrm{~B} 2-\mathrm{B} 4$

$\mathrm{B} 5{ }^{\mathrm{B}} 2-\mathrm{B} 5$

\begin{tabular}{|l|l|l|l|l|c|c|c|c|c|}
\hline 1 & 0 & 195,76 & $-16,93$ & $-5,12$ & 69,32 & $-2,56$ & 0 & 0 & 0 \\
\hline 0 & 1 & $-4,17$ & 0,75 & 0,23 & $-2,56$ & 0,09 & 0 & 0 & 0 \\
\hline 0 & 0 & 272,14 & $-2,05$ & $-27,56$ & $-195,77$ & 4,17 & 1 & 0 & 0 \\
\hline 0 & 0 & $-2,05$ & 128,69 & 0,98 & 16,93 & $-7,5$ & 0 & 1 & 0 \\
\hline 0 & 0 & $-27,56$ & 0,98 & 6,92 & 5,12 & $-0,23$ & 0 & 0 & 1 \\
\hline
\end{tabular}

B3/272,14

\begin{tabular}{|l|l|l|l|l|c|c|c|c|c|}
\hline 1 & 0 & 195,76 & $-16,93$ & $-5,12$ & 69,32 & $-2,56$ & 0 & 0 & 0 \\
\hline 0 & 1 & $-4,17$ & 0,75 & 0,23 & $-2,56$ & 0,09 & 0 & 0 & 0 \\
\hline 0 & 0 & 1 & $-0,007$ & $-0,10$ & $-0,72$ & 0,02 & 0,003 & 0 & 0 \\
\hline 0 & 0 & $-2,05$ & 128,69 & 0,98 & 16,93 & $-7,5$ & 0 & 1 & 0 \\
\hline 0 & 0 & $-27,56$ & 0,98 & 6,92 & 5,12 & $-0,23$ & 0 & 0 & 1 \\
\hline
\end{tabular}

$\mathrm{B} 1 * \mathrm{~B} 3-\mathrm{B} 1$

$\mathrm{B} 2 * \mathrm{~B} 3-\mathrm{B} 2$

B4*B3-B4

B5*B3-B5 


\begin{tabular}{|l|l|l|l|l|c|c|c|c|c|}
\hline 1 & 0 & 0 & $-15,45$ & 14,70 & 210,16 & $-5,56$ & $-0,72$ & 0 & 0 \\
\hline 0 & 1 & 0 & 0,72 & $-0,19$ & $-5,56$ & 0,16 & 0,02 & 0 & 0 \\
\hline 0 & 0 & 1 & $-0,007$ & $-0,10$ & $-0,72$ & 0,02 & 0,003 & 0 & 0 \\
\hline 0 & 0 & 0 & 128,67 & 0,77 & 15,45 & $-0,71$ & 0,007 & 1 & 0 \\
\hline 0 & 0 & 0 & 0,77 & 4,13 & $-14,70$ & 0,19 & 0,10 & 0 & 1 \\
\hline
\end{tabular}

B $4 / 128,67$

\begin{tabular}{|l|l|l|l|l|c|c|c|c|c|}
\hline 1 & 0 & 0 & $-15,45$ & 14,70 & 210,16 & $-5,56$ & $-0,72$ & 0 & 0 \\
\hline 0 & 1 & 0 & 0,72 & $-0,19$ & $-5,56$ & 0,16 & 0,02 & 0 & 0 \\
\hline 0 & 0 & 1 & $-0,007$ & $-0,10$ & $-0,72$ & 0,02 & 0,003 & 0 & 0 \\
\hline 0 & 0 & 0 & 1 & 0,006 & 0,12 & $-0,005$ & 0,00 & 0,007 & 0 \\
\hline 0 & 0 & 0 & 0,77 & 4,13 & $-14,70$ & 0,19 & 0,10 & 0 & 1 \\
\hline
\end{tabular}

$B 1 * B 4-B 1$

$\mathrm{B} 2 * \mathrm{~B} 4-\mathrm{B} 2$

B3*B4-B3

B5*B4-B5

\begin{tabular}{|c|c|l|l|l|c|c|c|c|c|}
\hline 1 & 0 & 0 & 0 & 14,79 & 212,01 & $-5,65$ & $-0,72$ & 0,12 & 0 \\
\hline 0 & 1 & 0 & 0 & $-0,19$ & $-5,65$ & 0,16 & 0,02 & $-0,005$ & 0 \\
\hline 0 & 0 & 1 & 0 & $-0,10$ & $-0,72$ & 0,02 & 0,003 & 0,00 & 0 \\
\hline 0 & 0 & 0 & 1 & 0,006 & 0,12 & $-0,005$ & 0,00 & 0,007 & 0 \\
\hline 0 & 0 & 0 & 0 & 4,12 & $-14,79$ & 0,19 & 0,10 & $-0,006$ & 1 \\
\hline
\end{tabular}

B $5 / 4,12$

\begin{tabular}{|c|c|c|l|l|c|c|c|c|c|}
\hline 1 & 0 & 0 & 0 & 14,79 & 212,01 & $-5,65$ & $-0,72$ & 0,12 & 0 \\
\hline 0 & 1 & 0 & 0 & $-0,19$ & $-5,65$ & 0,16 & 0,02 & $-0,005$ & 0 \\
\hline 0 & 0 & 1 & 0 & $-0,10$ & $-0,72$ & 0,02 & 0,003 & 0,00 & 0 \\
\hline 0 & 0 & 0 & 1 & 0,006 & 0,12 & $-0,005$ & 0,00 & 0,007 & 0 \\
\hline 0 & 0 & 0 & 0 & 1 & $-3,59$ & 0,05 & 0,02 & $-0,001$ & 0,24 \\
\hline
\end{tabular}

$B 1 * B 5-B 1$

$\mathrm{B} 2{ }^{*} \mathrm{~B} 5-\mathrm{B} 2$

$\mathrm{B} 3{ }^{*} \mathrm{~B} 5-\mathrm{B} 3$

$\mathrm{B} 4{ }^{*} \mathrm{~B} 5-\mathrm{B} 4$

- Ambil matriks yang ada di sebelah kanan

\begin{tabular}{|l|l|l|l|l|c|c|c|c|c|}
\hline 1 & 0 & 0 & 0 & 0 & 265,11 & $-6,35$ & $-1,08$ & 0,14 & $-3,59$ \\
\hline 0 & 1 & 0 & 0 & 0 & $-6,35$ & 0,17 & 0,02 & $-0,005$ & 0,05 \\
\hline 0 & 0 & 1 & 0 & 0 & $-1,08$ & 0,02 & 0,006 & $-0,00$ & 0,02 \\
\hline 0 & 0 & 0 & 1 & 0 & 0,14 & $-0,005$ & $-0,00$ & 0,007 & $-0,001$ \\
\hline 0 & 0 & 0 & 0 & 1 & $-3,59$ & 0,05 & 0,02 & $-0,001$ & 0,24 \\
\hline
\end{tabular}

- Hasil perhitungan matriks invers

\begin{tabular}{|c|c|c|c|c|}
\hline 265,11 & $-6,35$ & $-1,08$ & 0,14 & $-3,59$ \\
\hline$-6,35$ & 0,17 & 0,02 & $-0,005$ & 0,05 \\
\hline$-1,08$ & 0,02 & 0,006 & $-0,00$ & 0,02 \\
\hline 0,14 & $-0,005$ & $-0,00$ & 0,007 & $-0,001$ \\
\hline$-3,59$ & 0,05 & 0,02 & $-0,001$ & 0,24 \\
\hline
\end{tabular}

- Kalikan hasil perhitungan matriks A dengan B dengan cara baris di kalikan kolom

A

$\mathrm{X} B$

\begin{tabular}{|c|c|c|c|c|c|}
\hline 265,11 & $-6,35$ & $-1,08$ & 0,14 & $-3,59$ & 1041,7 \\
\hline$-6,35$ & 0,17 & 0,02 & $-0,005$ & 0,05 & 28050,28 \\
\hline$-1,08$ & 0,02 & 0,006 & $-0,00$ & 0,02 & 86530,6 \\
\hline 0,14 & $-0,005$ & $-0,00$ & 0,007 & $-0,001$ & 3431,14 \\
\hline$-3,59$ & 0,05 & 0,02 & $-0,001$ & 0,24 & 953,9 \\
\hline
\end{tabular}

\footnotetext{
A $\quad=265,11 * 1041,7-6,35 * 28050,28-1,08 * 86530,6+0,14 * 3431,14-3,59 * 953,9$

$=1592,45$

b1 $=-6,35 * 1041,7+0,17 * 28050,28+0,02 * 86530,6-0,005 * 3431,14-0,05 * 953,9$

$=32,44$

b2 $=-1,08 * 1041,7+0,02 * 28050,28+0,006 * 86530,6-0,00 * 3431,14-0,02 * 953,9$

$=7,48$
} 
b3

$$
\begin{aligned}
& =0,14 * 1041,7-0,005 * 28050,28-0,00 * 86530,6+0,007 * 3431,14-0,001 * 953,9 \\
& =\mathbf{1 , 3 0} \\
& =-3,59 * 1041,7+0,05 * 28050,28+0,02 * 86530,6-0,001 * 3431,14-0,24 * 953,9 \\
& =\mathbf{5 7 , 3 3}
\end{aligned}
$$

b4

5. Setelah hasil perhitungan didapat maka dibuat model persamaan regresi linear berganda

$$
\mathrm{Y}=1592,45-32,44 * \mathrm{X} 1-7,48 * \mathrm{X} 2+1,30 * \mathrm{X} 3-57,33 * \mathrm{X} 4
$$

Setelah di peroleh persamaan regresi linear berganda untuk perhitungan pada bulan januari, selanjutnya lakukan perhitungan yang sama pada tiap bulan di tahun 2018. Dan berikut hasil Perhitungan Persamaan Regresi Linear Berganda untuk prediksi curah hujan perbulan tahun 2019 :

Tabel 4. Hasil Persamaan Regresi Linear Berganda

\begin{tabular}{|c|l|l|}
\hline No & \multicolumn{1}{|c|}{ Bulan } & \multicolumn{1}{c|}{ Persamaan Regresi Linear Berganda } \\
\hline 1 & Januari & $\mathrm{Y}=1592,45-32,44 * \mathrm{X} 1-7,48 * \mathrm{X} 2+1,30 * \mathrm{X} 3-57,33 * \mathrm{X} 4$ \\
\hline 2 & Februari & $\mathrm{Y}=542,11-8,78 * \mathrm{X} 1-2,99 * \mathrm{X} 2+0,79 * \mathrm{X} 3-21,85 * \mathrm{X} 4$ \\
\hline 3 & Maret & $\mathrm{Y}=-265,54+6,32 * \mathrm{X} 1+1,68 * \mathrm{X} 2+1,98 * \mathrm{X} 3-31,26 * \mathrm{X} 4$ \\
\hline 4 & April & $\mathrm{Y}=-434,49+8,51 * \mathrm{X} 1+2,77 * \mathrm{X} 2+1,41 * \mathrm{X} 3-21,10 * \mathrm{X} 4$ \\
\hline 5 & Mei & $\mathrm{Y}=-91,04-0,10 * \mathrm{X} 1+1,62 * \mathrm{X} 2-1,08 * \mathrm{X} 3-15,04 * \mathrm{X} 4$ \\
\hline 6 & Juni & $\mathrm{Y}=49,42-1,62 * \mathrm{X} 1+0,26 * \mathrm{X} 2-2,46 * \mathrm{X} 3-0,77 * \mathrm{X} 4$ \\
\hline 7 & Juli & $\mathrm{Y}=0+0 * \mathrm{X} 1+0 * \mathrm{X} 2+0 * \mathrm{X} 3+0 * \mathrm{X} 4$ \\
\hline 8 & Agustus & $\mathrm{Y}=0+0 * \mathrm{X} 1+0 * \mathrm{X} 2+0 * \mathrm{X} 3+0 * \mathrm{X} 4$ \\
\hline 9 & September & $\mathrm{Y}=-295,42+7,66 * \mathrm{X} 1+1,47 * \mathrm{X} 2-4,26 * \mathrm{X} 3+13,40 * \mathrm{X} 4$ \\
\hline 10 & Oktober & $\mathrm{Y}=-553,74+16,91 * \mathrm{X} 1+1,107 * \mathrm{X} 2-1,27 * \mathrm{X} 3+0,55 * \mathrm{X} 4$ \\
\hline 11 & November & $\mathrm{Y}=134,46-3,56 * \mathrm{X} 1-0,39 * \mathrm{X} 2-1,41 * \mathrm{X} 3+24,52 * \mathrm{X} 4$ \\
\hline 12 & Desember & $\mathrm{Y}=-88,90+6,95 * \mathrm{X} 1-0,87 * \mathrm{X} 2-020 * \mathrm{X} 3-1,10 * \mathrm{X} 4$ \\
\hline
\end{tabular}

Setelah di dapat rumus persaman regresi linear selanjutnya kita hitung jumlah prediksi curah hujan pada tahun 2019 menggunakan rumus persamaan regresi linear berganda. Hasilnya sebagai berikut

Table 5. Perbandingan Data hasil observasi dengan prediksi

\begin{tabular}{|c|l|r|r|}
\hline No & \multicolumn{1}{|c|}{ Bulan } & Observasi & \multicolumn{1}{|c|}{ Prediksi } \\
\hline 1 & Januari & 333,70 & 690,58 \\
\hline 2 & Februari & 689 & 872,32 \\
\hline 3 & Maret & 649,2 & 957,02 \\
\hline 4 & April & 673 & 667,79 \\
\hline 5 & Mei & 299,1 & 153,4 \\
\hline 6 & Juni & 0 & 90,69 \\
\hline
\end{tabular}

Secara umum hasil prediksi curah hujan bulanan dengan menunjukan hasil yang lebih besar (over estimate) dari nilai aktual curah hujan bulanan tahun 2019 kecuali pada bulan april dan mei.

Berdasarkan Tabel diatas, maka didapatkan output grafik perbandingan antara observasi dan prediksi sebagai berikut : 


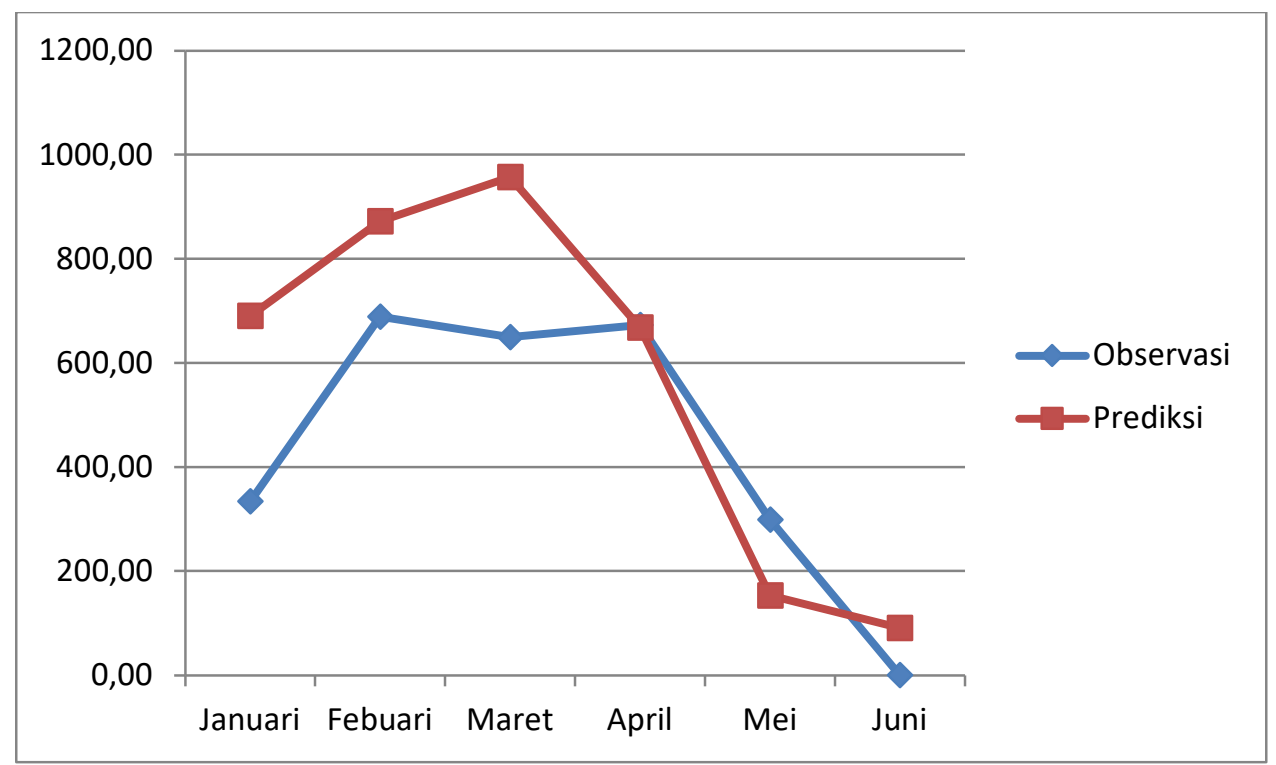

Grafik1. Perbandingan curah hujan hasil observasi dengan prediksi tahun 2019

Pada grafik diatas menjelaskan tentang perbandingan jumlah curah hujan perbulan dari hasil data observasi dengan data prediksi yang dilakukan dengan metode regresi linear berganda pada data uji bulan januari sampai juni tahun 2019. Grafik yang terbentuk memperlihatkan hasil prediksi yang lebih besar pada bulan januari, febuari, maret dan juni. Sedangakan hasil prediksi yang lebih kecil pada bulan mei dan hasil prediksi yang paling mendekati berada pada bulan april dengan pola grafik yang hapir serupa.

Tahap selanjutnya adalah menguji data yang dihasilkan oleh metode Regresi Linear Berganda Dengan menggunakan Metode Root Mean Square Error (RMSE) dan perhitungan nilai koefisien korelasi.

Table 6. Perhitungan Menentukan RMSE dan Koefisien Korelasi

\begin{tabular}{|c|c|c|c|c|c|c|}
\hline $\mathbf{Y i}$ & $\bar{\Upsilon} \boldsymbol{i}$ & $\mathbf{Y}^{*}$ & $\boldsymbol{Y} \boldsymbol{i}-\bar{Y} \boldsymbol{i}$ & $\mathbf{Y i}-\mathbf{Y}^{*}$ & $(Y i-\bar{Y} i)^{2}$ & $\left(\mathbf{Y i}-\mathbf{Y}^{*}\right)^{2}$ \\
\hline 333,70 & 690,58 & 10,76 & $-356,88$ & 322,94 & 127363,33 & 104287,33 \\
\hline 689 & 872,32 & 25,52 & $-183,32$ & 663,48 & 33606,22 & 440207,68 \\
\hline 649,2 & 957,02 & 20,94 & $-307,82$ & 628,26 & 94753,15 & 394708,20 \\
\hline 673 & 667,79 & 25,91 & 5,21 & 647,09 & 27,14 & 418723,48 \\
\hline 299,1 & 153,4 & 11,964 & 145,70 & 287,14 & 21228,49 & 82447,08 \\
\hline 0 & 90,69 & 0 & $-90,69$ & 0 & 8224,68 & 0 \\
\hline \multicolumn{5}{|c|}{ Jumlah } & 285203,02 & 1440373,76 \\
\hline
\end{tabular}

- $\quad$ Menghitung RMSE

$$
\mathrm{RMSE}=\left[\frac{1}{N} \sum_{n=1}^{N}\left(f_{n}-r_{n}\right)^{2}\right]^{\frac{1}{2}} \quad \text { Atau } \quad \text { RMSE }=\sqrt{\frac{\sum_{i=1}^{n}(Y i-\bar{Y} i)^{2}}{n}}
$$

Ket :

Yi atau $f_{n}=$ Data curah hujan hasil observasi

$\overline{\mathrm{Y}} \mathrm{i}$ atau $r_{n}=$ Data curah hujan hasil prediksi

$\mathrm{n}=$ jumlah data set tahun 2019

$$
\begin{aligned}
\operatorname{RMSE} & =\sqrt{\frac{\sum_{i=1}^{n}(Y i-\bar{Y} i)^{2}}{n}} \\
& =\sqrt{\frac{285203,02}{170}} \\
& =40,96
\end{aligned}
$$


- Menghitung Nilai Koefisien Korelasi

$$
\begin{aligned}
& r=\sqrt{1-\frac{\sum(Y-\bar{Y})^{2}}{\sum(Y-Y *)^{2}}} \\
& r=\sqrt{1-\frac{285203,02}{1440373,76}} \\
& r=0,90
\end{aligned}
$$

Dari hasil perhitungan menunjukan bahwa di dapat nilai koefisien korelasi antara prediksi curah hujan bulanan dengan prediktor suhu, kelembapan, lama penyinaran dan kecepatan angin terhadap data observasi di Kabupaten Majalengka di dapat nilai koefisien korelasinya sebesar $r=0,90$ dan nilai RMSEnya sebesar $46,26 \%$.

\section{KESIMPULAN}

Berdasarkan dari uraian yang telah dipaparkan oleh penulis tersebut, maka dapat ditarik beberapa kesimpulan sebagai berikut:

1. Prediksi curah hujan bulanan di Kabupaten Majalengka menunjukan nilai prediksi paling baik pada bulan April. Nilai prediksi total hujan bulanan dengan predictor suhu, kelembapan, lama penyinaran dan kecepatan angin menunjukan hasil over estimate ( lebih besar dari nilai actual) dari nilai observasinya. Prediksi curah hujan bulanan menghasilkan nilai koefisensi korelasi yang kuat dan RMSE yang baik yaitu sebesar $r=0,90$ dan RMSE $=40,96 \%$.

2. Prediksi jumlah curah hujan bulanan akan terinterpretasikan cukup baik apabila kondisi cuaca di suatu wilayah dalam keadaan normal (tidak terdapat anomali cuaca dan iklim) sehingga mempengaruhi pada kondisi fluktuasi curah hujan.

\section{DAFTAR PUSTAKA}

[1] Diana Cahaya Siregar, dkk., 2018, "Simulasi Prediksi Total Hujan Bulanan di Tanjungpinang (Studi Kasus Tahun 2017)", Jurnal Statistika dan Aplikasinya, vol 2, pp 17.

[2] Aristya Ardhitama, 2012, " Simulasi Prakiraan Jumlah Curah Hujan Dengan Menggunakan Data Parameter Cuaca (Study Kasus Di Kota Pekanbaru Tahun 2012)”.

[3] Moch. Abdul Mukid dan Sugito, 2013, "Model Prediksi Curah Hujan Dengan Pendekatan Regresi Proses Gaussian (Study Kasus di Kabupaten Grobogan)”, Media Statistika, vol. 6, no. 2, pp 113-122.

[4] Akhmad Fadholi, 2013, "Persamaan Regreasi Prediksi Curah Hujan Bulanan Menggunakan Data Suhu dan Kelembapan Udara di Ternate”, Statistika, vol. 13, no. 1, pp 7-16.

[5] Putramulyo, Sastriogi dan Siti Alaa, 2018, "Prediksi Curah Hujan Bulanan di Kota Samarinda Menggunakan Persamaan Regresi Dengan Prediktor Data Suhu Dan Kelembapan Udara", Eigen Mathematics Journal, vol. 1, no. 2, pp 13-16. 